\title{
Modern High Strength Concrete with Unique Properties
}

\author{
Valentina Soloviova $^{1 *}$, Dmitriy Soloviov ${ }^{2}$, Irina Stepanova ${ }^{3}$ \\ ${ }^{I}$ Doctor of Technical Sciences, Professor of Department of «Engineering chemistry and natural science», Emperor Alexander I \\ St.Petersburg State Transport University (PGUPS), Moskovsky pr., 9, 190031, Saint-Petersburg, Russia. Email: soloviova- \\ pgups@mail.ru \\ 2 Candidate of Technical Sciences, Engineer of the Department of «Engineering chemistry and natural science», Emperor Alexander I \\ St.Petersburg State Transport University (PGUPS), Moskovsky pr., 9, 190031, Saint-Petersburg, Russia. Email: sokrat-lab@mail.ru \\ ${ }^{3}$ Candidate of Technical Sciences, Associate Professor, Department of «Engineering chemistry and natural science», », Emperor Alex- \\ ander I St.Petersburg State Transport University (PGUPS), Moskovsky pr., 9, 190031, Saint-Petersburg, Russia.
}

*Corresponding author E-mail: ivstepanova88@mail.ru

\begin{abstract}
Artificial stone has been one of the most common materials in construction for a long time by now. Despite the variety of types of concrete, the composite is in constant motion of development and improvement. The common use of high strength composite is for the construction of high-rise buildings or projects complex in geometry.

This article suggests preparing high-strength cementitious composites by complex chemical activation using chemical admixtures in combination with reactive aggregates, as they give good hydration (hardening) of concrete. Research results confirm that this practice of complex chemical activation of cement gives high-strength concrete with better strength, deformation and durability properties.
\end{abstract}

Keywords: concrete, strength, durability, hardness, resistance to aggressive media, chemical activation, hydration, reaction rate, heat conservation.

\section{Introduction}

Current building science develops towards the construction of unique and complex buildings and structures, as well as towards their renovation, so the use of high-strength binders and concretes made with them is essential.

Because concretes have a range of unique properties, they are widely applied in the construction of essential structures, such as high-rise buildings, road and airfield coverings, transmission towers, and special facilities.

Such an application calls for the use of high-strength concrete with a surface enhanced against abrasion, which has good crack resistance, and resistance to aggressive media, high deformation and durability properties.

High-strength concrete of new generation has a wide range of properties, so they are often broken into two blocks.

Parameters of a fresh concrete mixture compose the first block [22]:

- $\quad$ consistency with cone flow diameter range 65 to $70 \mathrm{~cm}$;

- $\quad$ compaction degree of 1.0 to 1.4 ;

- $\quad$ flow properties remaining for not less than 3 to 4 hours;

- $\quad$ minimal delamination;

- $\quad$ air content less than $1 \%$.

The second block houses characteristics of hardened composite [23]:

- $\quad$ compressive strength at range of 50 to $100 \mathrm{MPa}$; flexural strength of at least $4 \mathrm{MPa}$;

- $\quad$ density and pore structure;

- $\quad$ high abrasion resistance;
W10;

frost resistance above F400 and water resistance above

- $\quad$ water absorption capacity (less than $1 \%$ );

Low modulus of elasticity.

The creation of such concrete is possible only by chemical activation, which can give new hydrated phases of a more complex composition, characterized by better surface hardness and reduced solubility. Hydrated specimens will have a special structure, such as fibrous structure, for example, which has a reinforcing effect on the concrete being formed [1-5].

Unlike chemical activation, hating is less effective, as the increase in the rate of hydration comes usually without the formation of new phases. Instead, a calcium-silicate-hydrate analog appears in the form of CSH (I) group hydrosilicate, characterized by a large specific surface area. This phase gives a dense structure of concrete. Concrete consolidation is an essential step in concrete making, but alone it is not enough to produce concrete with unique properties.

This is when chemical activation comes in handy, performed by using chemical admixture in combination with a reactive aggregate.

Chemical admixture alters the properties of concrete, extending its workability, making the structure uniform, and eliminating delamination and water loss. Therefore, the admixture must be of polyfunctional action (activating and plasticizing actions).

The new generation of admixtures is made from highly effective surfactants (aqueous solutions of polycarboxylate comb-polymers with either side chains of medium length, commonly known as PCEs) in combination with polymeric high-molecular compounds, which form new polymer chains by interaction [6-10]. 
These new formations must permeate the concrete mixture throughout the entire volume, increasing its kinetic stability, preventing delamination and water loss so that the mixture forms into a uniform composite.

The reactivity of chemical admixture can be provided by the use of nanoparticles, such aqueous dispersions of silicon dioxide nanoparticles ( $\mathrm{SiO} 2 \cdot \mathrm{nH} 2 \mathrm{O}$ ), which in chemical composition are similar to ingredients that go into fresh concrete, but have enhanced reactivity. Nanoparticles, unlike molecules, ions or atoms, have high surface free energy and a certain $\mathrm{pH}$. Their special structure is responsible for high mobility of $\mathrm{SiO} 2 \cdot \mathrm{nH} 2 \mathrm{O}$ nanoparticles so they show improved reactive and dispersion activities. Considering the character of these nanoparticles, they can affect the hydration of mineral concrete components. Because of high reactivity, aqueous dispersions of silica nanoparticles can react with ingredients and newly formed phases in hardening concrete mixture [11-16].

The use of reactive aggregate should increase the density and strength of the composite, and grant the concrete with unique properties (improved deformation and durability properties).

The advisable reactive aggregate to use are the magnesian limestones, modified with alkali metal salts, which reveal their reactivity. In hydrated cement paste, the supplement is capable of generating super-strong calcium magnesium silicates and basic fibrous, acicular or elongated prismatic crystals of calcium carbonates, characterized by increased hardness and good chemical stability in aggressive media [17-21].

\section{Methods}

The admixture performance and the effect of its components, as well as the performance of a modified reactive aggregate, were evaluated by measuring the compressive strength, flexural strength, water absorption and density of concrete. For trial, concrete with $400\left(\mathrm{~kg} / \mathrm{cm}^{2}\right)$ strength was produced as the most common concrete in use for the construction of essential structures. For this type of concrete production, Portland cement CEM I 42.5 $N$ was used (GOST 31108-2016), sand intended for construction applications with the fineness modulus of 2.26, (GOST 87362014) and granite fractions 5-10 mm (GOST 8269-93).

The major admixture components were:

polycarboxylate-based polymers as $25 \%$ aqueous solution (density $\rho=1.038 \mathrm{~g} / \mathrm{cm}^{3}$ at $\mathrm{pH} 6.5$ );

- $\quad$ polymeric high-molecular compounds with 19 to 21 carbon atoms in a chain (density $\rho=0.97 \mathrm{~g} / \mathrm{cm}^{3}$ at $\mathrm{pH} 10.5$ ); aqueous dispersions of silicon dioxide nanoparticles, prepared by dispersion with colloidal solution (sol) of silicic acid, which density was $\rho=1.014 \mathrm{~g} / \mathrm{cm}^{3}$ at $\mathrm{pH} 10.5$ ).

For concrete production, the following materials were used (proportion expression provided in $\mathrm{kg}$ per $1 \mathrm{~m}^{3}$ of concrete mix):

- $\quad$ Portland cement CEM I $42.5 \mathrm{~N}$ : 430;

- $\quad$ Sand with the fineness modulus of 2.26: 655;

- $\quad$ Granite fraction: 1025

- $\quad$ Water, determined by trial and error to achieve a Mix P4 plastic level (settlement 16 to $20 \mathrm{~m}$ ): 250 .

The procedure of determining concrete strength parameters was performed in accordance with the GOST 10180-2012. Some samples of concrete mix were taken to normal hardening until 28 days, and some to steam curing at the range of $78 \pm 2$ degrees Celsius. Curing regime: first 3 hours - pre-setting period, when specimens were cured by standard; 3 hours - period of temperature rise from $20^{\circ} \mathrm{C}$ to $78^{\circ} \mathrm{C} ; 6$ hours - an isothermal period, when curing was performed under isothermal conditions at the range of $78 \pm 2$ degrees Celsius; last 3 hours - a cooling period, when the temperature dropped to $-40^{\circ} \mathrm{C}$.

Besides the properties mentioned above, analysis was applied to frost resistance (GOST 10060-2012) and abrasion resistance properties (GOST 13087-81). The consistency and accuracy of trial results were validated by XRD and differential-thermal data provided by comprehensive physico-chemical studies of hardened paste samples.

\section{Results and Discussion.}

Results of physico-mechanical studies are presented in Table 1.

Table 1. Trials to Find Rational Proportion between Components in an Admixture added to Trial Concrete

\begin{tabular}{|c|c|c|c|c|c|c|c|c|c|}
\hline \multirow[b]{3}{*}{ № } & \multirow[b]{3}{*}{ 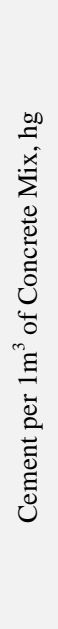 } & \multirow[b]{3}{*}{ 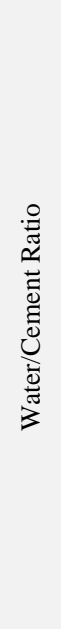 } & \multirow[b]{3}{*}{ 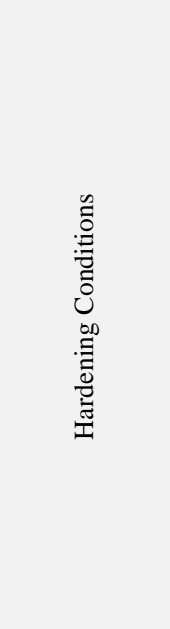 } & \multicolumn{3}{|c|}{ Admixture, $\%$ in Total Cement } & \multirow[b]{3}{*}{ 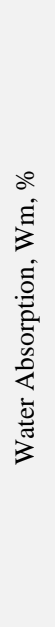 } & \multicolumn{2}{|c|}{ Strength at 28 Days, $\mathrm{MPa}$} \\
\hline & & & & \multicolumn{3}{|c|}{ Components } & & \multirow[b]{2}{*}{ 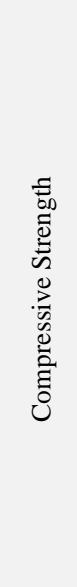 } & \multirow[b]{2}{*}{ 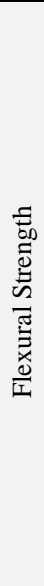 } \\
\hline & & & & 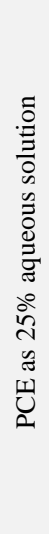 & 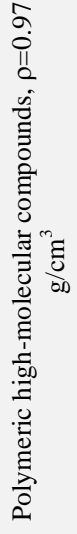 & 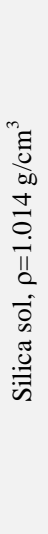 & & & \\
\hline 1 & 430 & 0.62 & Steam Curing & - & - & - & 4.8 & 38.9 & 4.6 \\
\hline 2 & 430 & 0.62 & \multirow{6}{*}{ Normal } & - & - & - & 4.9 & 39.6 & 4.6 \\
\hline 3 & 430 & 0.58 & & 0.6 & - & - & 4.4 & 41.8 & 4.9 \\
\hline 4 & 430 & 0.54 & & 0.8 & - & - & 3.9 & 43.2 & 5.1 \\
\hline 5 & 430 & 0.52 & & 1.0 & - & - & 3.6 & 47.2 & 5.6 \\
\hline 6 & 430 & 0.51 & & 1.2 & - & - & 3.5 & 48.1 & 5.7 \\
\hline 7 & 430 & 0.50 & & 1.5 & - & - & 3.4 & 46.4 & 5.5 \\
\hline 8 & 430 & 0.52 & \multirow{5}{*}{ Normal } & 1.0 & - & - & 3.6 & 47.2 & 5.6 \\
\hline 9 & 430 & 0.51 & & 1.0 & 0.2 & - & 3.3 & 48.0 & 5.8 \\
\hline 10 & 430 & 0.50 & & 1.0 & 0.4 & - & 3.2 & 48.9 & 6.1 \\
\hline 11 & 430 & 0.49 & & 1.0 & 0.6 & - & 3.2 & 49.1 & 6.2 \\
\hline 12 & 430 & 0.49 & & 1.0 & 0.8 & - & 3.3 & 49.6 & 6.3 \\
\hline
\end{tabular}




\begin{tabular}{|c|c|c|c|c|c|c|c|c|c|}
\hline 13 & 430 & 0.50 & \multirow{4}{*}{ Normal } & 1.0 & 0.4 & - & 3.3 & 48.9 & 6.1 \\
\hline 14 & 430 & 0.49 & & 1.0 & 0.4 & 0.4 & 3.1 & 52.4 & 6.6 \\
\hline 15 & 430 & 0.48 & & 1.0 & 0.4 & 0.6 & 2.9 & 58.6 & 7.6 \\
\hline 16 & 430 & 0.47 & & 1.0 & 0.4 & 0.8 & 2.8 & 59.0 & 7.5 \\
\hline
\end{tabular}

Table 1 shows that PCE administrated as $25 \%$ aqueous solution with a dosage of $1 \%$ by cement weight gives an plasticizing effect by reducing the $\mathrm{W} / \mathrm{C}$ ratio from 0.62 to 0.52 (16\% drop) and improving the compressive strength by $19 \%$. Thus, a naturally made assumption is that concrete strength improves due to consolidation by plasticizing action.

High molecular compounds in combination with $25 \%$ aqueous solution increase the concrete mix density without a significant reduction in the $\mathrm{W} / \mathrm{C}$ ratio, apparently due to a branched polymer chain system generated.

PCE together with high molecular compounds improve the compressive strength by $23 \%$ and the flexural strength up to $31 \pm 32 \%$ (relationship range 0.125 )

The next component in the admixture being developed is a silicic acid sol containing $\mathrm{SiO} 2 \cdot \mathrm{nH} 2 \mathrm{O}$ nanodispersions, assuming that they will significantly increase the concrete mix density. The improvement will occur because of a reduction in water absorption by $41 \%$, down to $2.9 \%$. This is when the compressive strength will be improved, up to $48 \%$. The increase in flexural strength (up to $65 \%$ ) oversteps the compressive strength ad density properties. This contributes to a better resistance to cracking ( $11 \%$ increment), due to reinforcement with new phases generated Data from Trial 2 (Table 1), by contrast to Trial 1, show that at the age of 28 days, concrete without additional chemical activation in both hardening phases has properties of concrete with 400 $\left(\mathrm{kg} / \mathrm{cm}^{2}\right)$ strength.

Data from Trial 15 shows that developed chemical admixture gives a composite with better physical and mechanical characteristics than just heat treatment. Besides, it improves compressive strength by $51 \%$ relative to concrete strength after heat treatment.

Based on data from Table 1, a rational admixture composition was defined:

- $\quad$ PCE as $25 \%$ aqueous solution (density $1.038 \mathrm{~g} / \mathrm{cm}^{3}, \mathrm{pH}$ ranging between $6.5 \%$ and $47.6 \%$ );

- aqueous solution of high-molecular compounds (density $0.97 \mathrm{~g} / \mathrm{cm}^{3}, \mathrm{pH}$ ranging between $10.5 \%$ and $23.8 \%$ );

- $\quad$ colloidal solution of silicic acid (density $1.014 \mathrm{~g} / \mathrm{cm}^{3}$, $\mathrm{pH}$ ranging between $3.5 \%$ and $28.6 \%$ ).

The rational amount of developed admixture to add in the concrete mix was determined from the change in the produced concrete strength at 28 days. The amount of cement used was $430 \mathrm{~kg} / \mathrm{m}^{3}$. Dosages of admixture added were expressed in percentage to cement weight. Results are shown in Figure 1.

\section{Relationship between Trial Concrete Strength Characteristics and the Concentration of Chemical Admixture}

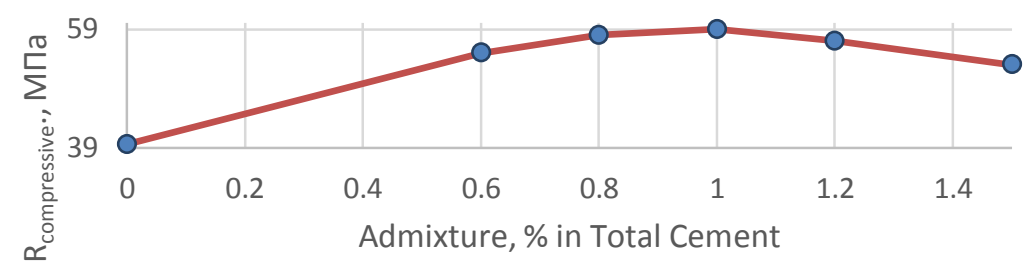

Fig. 1: Relationship between Trial Concrete Strength Characteristics and the Concentration of Chemical Admixture

Figure 1 shows that with an admixture added to the mix (dosage: $0.9-1.1 \%$ by cement weight), compressive strength of concrete will reach its high, so the $1.0 \%$ dosage was further applied to activate the concrete in any trial performed.

For even better density, deformation and durability properties, chemical activation of a modified concrete mix was performed in combination with a reactive aggregate. The aggregate used was the floured magnesia limestone (specific surface area $320 \mathrm{~m}^{2} / \mathrm{kg}$ ) modified with sodium carbonate.

The rational amount of aggregate to add in the concrete mix was determined from the change in density, compressive and flexural strength of produced concrete. Results are shown in Table 2.

Table 2: Trials to Find Rational Amount of Reactive Aggregate using Physical and Mechanical Data on Trial Concreate Treated by Standard

\begin{tabular}{|c|c|c|c|c|c|c|c|}
\hline \multirow{2}{*}{ № } & \multirow{2}{*}{ Cement in $1 \mathrm{~m}^{3}$ of Concrete Mix, $\mathrm{kg}$} & \multirow{2}{*}{ Water/Cement Ratio } & \multirow{2}{*}{$\begin{array}{l}\text { Admixture, } \% \\
\text { in Total Cement }\end{array}$} & \multirow{2}{*}{$\begin{array}{c}\text { Reactive Aggregate, } \% \\
\text { in Total Cement }\end{array}$} & \multirow{2}{*}{ 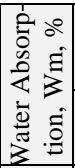 } & \multicolumn{2}{|c|}{ Strength at 28 Days, $\mathrm{MPa}$} \\
\hline & & & & & & Compressive Strength & Flexural Strength \\
\hline 1 & 3 & 4 & 5 & 6 & 7 & 8 & 9 \\
\hline 1 & 430 & 0.62 & - & - & 4.9 & 39.6 & 4.6 \\
\hline 2 & 430 & 0.48 & 1.0 & - & 2.9 & 58.6 & 7.6 \\
\hline 3 & 430 & 0.48 & 1.0 & 0.5 & 2.7 & 59.1 & 7.7 \\
\hline 4 & 430 & 0.475 & 1.0 & 1.0 & 2.3 & 60.3 & 8.0 \\
\hline 5 & 430 & 0.47 & 1.0 & 1.5 & 2.0 & 62.4 & 8.4 \\
\hline
\end{tabular}




\begin{tabular}{|l|c|c|c|c|c|c|}
\hline 6 & 430 & 0.465 & 1.0 & 2.0 & 1.8 & 6.7 \\
\hline 7 & 430 & 0.46 & 1.0 & 2.5 & 1.6 & 6.7 \\
\hline 8 & 430 & 0.48 & 1.0 & 3.0 & 1.7 & 64.8 \\
\hline 9 & 430 & 0.49 & 1.0 & 3.5 & 1.9 & 64.1 \\
\hline
\end{tabular}

Table 2 shows that adding of modified limestone aggregate to a modified concrete mix (dosage: $2.5 \%$ by cement weight) significantly modifies concrete properties (increases density, reduces water absorption by $67.3 \%$, down to $1.6 \%$, and improves compressive strength by $67 \%$ ). The increase in flexural strength, up to $101 \%$, outstrips the compressive strength, apparently due to chemical interaction of modified magnesia limestone with the ingredients of activated concrete mix. This interaction results in the

formation of strong, fibrous calcium-magnesium hydroaluminosilicates.

The resistance of modified concrete to cracking increased by $18 \%$ at the critical stress intensity factor (CSIF) of $0.14 \%$, which is unique for high-strength concretes. Hence, produced concrete can be used in the construction of high-rise buildings.

Further studies were to determine physico-mechanical characteristics of modified concrete. Comparative research results are presented in Table 3.

Table 3: Comparative Data on Physical and Mechanical Properties of Trial Concretes Cured by Steam and under Normal Conditions of Hardening

\begin{tabular}{|c|c|c|c|c|c|c|c|c|c|c|}
\hline \multirow[b]{2}{*}{ № } & \multirow[b]{2}{*}{ 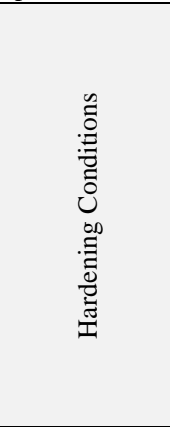 } & \multirow{2}{*}{ 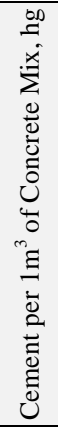 } & \multirow{2}{*}{ 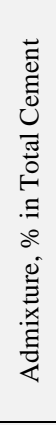 } & \multirow{2}{*}{ 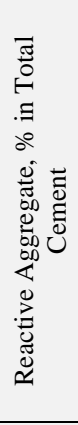 } & \multirow[b]{2}{*}{ 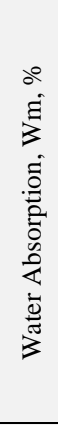 } & \multicolumn{2}{|c|}{ Strength at 28 Days, $\mathrm{MPa}$} & \multirow[b]{2}{*}{ 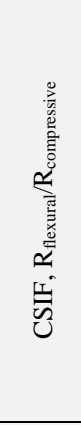 } & \multirow{2}{*}{ 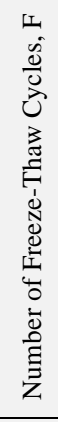 } & \multirow[b]{2}{*}{ 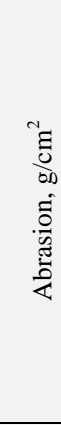 } \\
\hline & & & & & & 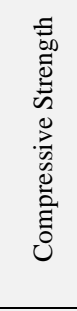 & 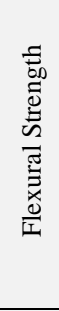 & & & \\
\hline 1 & 3 & 4 & 5 & 6 & 7 & 8 & 9 & 10 & 11 & 12 \\
\hline 1 & Steam Curing & 430 & - & - & 4.8 & 38.9 & 4.6 & 0.118 & 200 & 0.8 \\
\hline 2 & Normal & 430 & - & - & 4.9 & 39.6 & 4.6 & 0.116 & 200 & 0.85 \\
\hline 3 & Normal & 430 & 1.0 & - & 2.9 & 58.6 & 7.6 & 0.13 & 400 & 0.70 \\
\hline 4 & Normal & 430 & 1.0 & 2.5 & 1.6 & 66.1 & 9.2 & 0.14 & 600 & 0.53 \\
\hline
\end{tabular}

Note: $R_{\text {flexural }}$-flexural strength; $R_{\text {compressive }}$ - compressive strength.

The 28-days concretes, prepared by steam curing and standard curing without additional chemical activation, have comparatively the same characteristics of strength, density, frost and abrasion resistance.

A $1.0 \%$ portion of developed admixture added to a concrete mix was a significant boost to compressive strength and flexural strength of hardened formation. Thus, deformation property of concrete was improved, as evidenced from an increase in crack resistance by $12 \%$, up to 0.13 , due to the formation of new complex hydrate fibrous compounds, as well as from an increase in frost resistance to a twofold or so, due to a formation of uniform small pores.

Table 3 shows that a concrete mix modified with a developed admixture is quite effective. Besides the improved deformation characteristics, there are other improvements provided by the aggregate. The additional use of modified fine-grained reactive aggregate enhances chemical activation, since flexural strength increased to a twofold from prior value and the crack resistance

increases by $20 \%$, up to 0.14 . Frost resistance increased to a threefold.

Trial results were validated by XRD and differential-thermal data provided by comprehensive physico-chemical studies of hardened paste samples.

The trial was performed on a concrete with $400\left(\mathrm{~kg} / \mathrm{cm}^{2}\right)$ strength: - $\quad$ passed through steam curing with no prior chemical activation;

- $\quad$ hardened under normal conditions with no prior chemical activation;

- $\quad$ hardened under normal conditions subsequent to chemical activation with a developed admixture;

- $\quad$ hardened under normal conditions subsequent to chemical activation with a developed admixture in combination with a reactive aggregate.

The first stage was an X-ray phase analysis, which results are described below.

Sample 1 was a concrete without any additives, passed through steam curing. 


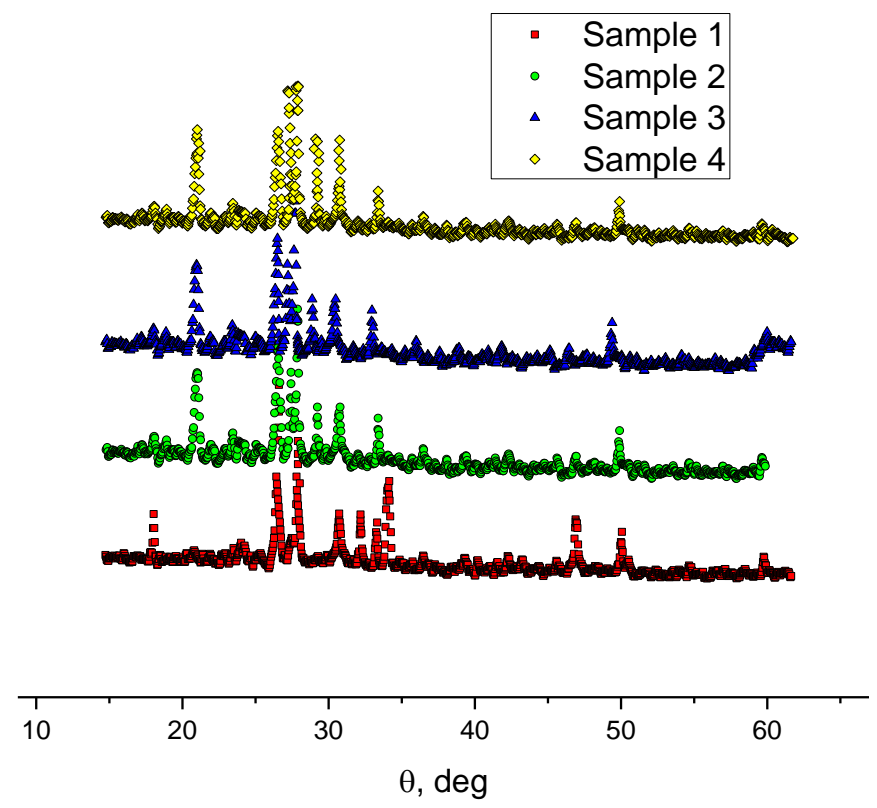

Fig 2: XRD data on samples 1-4.

The roentgenogram (Figure 2) displayed not only the appearance of typical minerals, but also lines of new material with d-spacing of $\mathrm{d} / \mathrm{n}=(12.5 ; 3.07 ; 2.80 ; 1.83) \cdot 10^{-10} \mathrm{~m}$, which correspond to partially crystallized CSH (I) group hydrosilicates, apparently with a $\mathrm{Ca} / \mathrm{Si} \approx 1$ ratio, as evidenced from the presence of a line with $\mathrm{d} / \mathrm{n}=12.5 \times 10^{-10} \mathrm{~m}$.

On the roentgenogram, new intense lines were also detected with $\mathrm{d}$-spacing of $\mathrm{d} / \mathrm{n}=(4.93 ; 2.63 ; 1.93) \cdot 10^{-10} \mathrm{~m}$, which are specific to $\mathrm{Ca}(\mathrm{OH})_{2}$.

$\mathrm{Ca}(\mathrm{OH})_{2}$ in the hardening system is a hydrolysis product of tricalcium silicate $\left(3 \mathrm{CaO} \cdot \mathrm{SiO}^{2}\right)$, which is a typical basic mineral of Portland cement:

$3 \mathrm{CaO} \cdot \mathrm{SiO}_{2}+(\mathrm{n}+1) \mathrm{H}_{2} \mathrm{O}=3 \mathrm{CaO} \cdot \mathrm{SiO}_{2} \cdot \mathrm{nH}_{2} \mathrm{O}+\mathrm{Ca}(\mathrm{OH})_{2}$, the more intensive the reaction is, the more $\mathrm{Ca}(\mathrm{OH})_{2}$ will be at the end.

X-ray data show intense lines specific to $\mathrm{Ca}(\mathrm{OH})_{2}$, which can indicate intensive hydration of portland cement during steam curing.

Sample 2 was a concrete without any additives, hardened under normal conditions.

As in the first case, lines were found on the roentgenogram with dspacing of $\mathrm{d} / \mathrm{n}=(12.5 ; 3.07 ; 2.80 ; 1.83) \cdot 10^{-10} \mathrm{~m}$, which correspond to partially crystallized CSH (I) group hydrosilicates. There were also lines specific to $\mathrm{Ca}(\mathrm{OH})_{2}$ with $\mathrm{d} / \mathrm{n}=(4.93 ; 2.63$; 1.93) $\cdot 10^{-10} \mathrm{~m}$

By comparing two roentgenograms made for samples 1 and 2, one can see that patterns and line intensity are almost the same, indicating hydration process of the same intensity in both concrete mixtures with no admixtures in them, and the conditions of hardening did not matter.

Sample 3 was a concrete with an admixture added, hardened under normal conditions.

The roentgenogram displayed lines with $d$-spacing of $d / n=(13.7$; $3.07 ; 2.80 ; 1.83) \cdot 10^{-10} \mathrm{~m}$, which correspond to partially crystallized CSH (I) group hydrosilicates, but $\mathrm{Ca} / \mathrm{Si}$ ration here, apparently, equals 0.8 , since no lines with $\mathrm{d} / \mathrm{n}=12.5 \times 10^{-10} \mathrm{~m}$ were found. Instead, new ones appeared with $\mathrm{d} / \mathrm{n}=13.7 \cdot 10^{-10} \mathrm{~m}$, which correspond to calcium silicate hydrate.

Lines with $\mathrm{d} / \mathrm{n}=(4.93 ; 2.63 ; 1.93) \cdot 10^{-10} \mathrm{~m}$, which are specific to $\mathrm{Ca}(\mathrm{OH})_{2}$, have a minimum intensity, so a very little Portlandite footprint can be found in the hardened stone.

Apparently, a decrease in $\mathrm{Ca}(\mathrm{OH})_{2}$ in the hardened activated composite came not with a decrease in hydration of tricalcium silicate, but with synthesis between the formed hydrolytic lime and the admixture component ( $\mathrm{SiO} 2$ nanodispersion). This assumption is supported by the fact that new lines with $d / n=(9.25$; $2.82 ; 2.47 ; 1.90) \cdot 10^{-10} \mathrm{~m}$, specific to a low-basic hydrosilicate $3 \mathrm{CaO} \cdot 6 \mathrm{SiO}_{2} \cdot 8 \mathrm{H}_{2} \mathrm{O}$ (matted-fibrous crystals of nekoite), were not found.

Instead, the picture shows lines with $\mathrm{d} / \mathrm{n}=(6.46 ; 5.74 ; 4.73 ; 3.19$; $2.74 ; 2.14) \cdot 10^{-10} \mathrm{~m}$, which may correspond to the complex hydrate compound $3 \mathrm{CaO} \cdot 2 \mathrm{SiO}_{2} \cdot 3 \mathrm{H}_{2} \mathrm{O}$, known as afwillite (elongated prismatic crystals). Afwillite is a quite hard material (4 on the Moh's scale), characterized by a lower solubility.

The formation of new phases, represented by low-basic hydrosilicates and silicates of more complex composition, imparts unique properties to hardened concrete (improved flexural strength, crack resistance and hardness).

Sample 4 was an activated concrete with an admixture added in combination with a reactive aggregate.

With an admixture used in combination with a reactive aggregate, the hydration of concrete mixture was high, as evidenced from the reduced height of lines on the roentgenogram with d-spacing of $\mathrm{d} / \mathrm{n}=(3.02 ; 2.77 ; 2.73 ; 2.60 ; 1.77) \cdot 10^{-10} \mathrm{~m}$, which are specific to tricalcium silicate $3 \mathrm{CaO} \cdot \mathrm{SiO}_{2}$, the major mineral in Portland cement.

By comparing two roentgenograms made for samples 3 and 4 , one can see lines specific to nekoite $\left(3 \mathrm{CaO} \cdot 6 \mathrm{SiO}_{2} \cdot 8 \mathrm{H}_{2} \mathrm{O}\right)$ and afvillite $\left(3 \mathrm{CaO} \cdot 2 \mathrm{SiO}_{2} \cdot 3 \mathrm{H}_{2} \mathrm{O}\right)$, but no lines specific to Portlandite, $\mathrm{Ca}(\mathrm{OH})_{2}$. It seems that Portlandite completely entered into the synthesis reaction with $\mathrm{SiO} 2$. The exclusion of hydrolytic lime is a good achievement that contributes to an increase in concrete resistance to aggressive media.

The new lines that appeared due to the formation of magnesium bicarbonate $\mathrm{MgCO}_{3} \cdot 3 \mathrm{H}_{2} \mathrm{O}$ were with $\mathrm{d} / \mathrm{n}=(3.85 ; 2.50 ; 3.55) \cdot 10^{-10}$ $\mathrm{m}$, and lines that appeared due to the formation of hydromagnesite $\mathrm{MgCO}_{3} \cdot \mathrm{Mg}(\mathrm{OH})_{2} \cdot 3 \mathrm{H}_{2} \mathrm{O}$ were with $\mathrm{d} / \mathrm{n}=(5.79 ; 2.90 ; 3.15) \cdot 10^{-10} \mathrm{~m}$. The magnesium-containing phases formed probably because of the reactive aggregate added, which was a magnesian limestone. Because of the increased hardiness of matted-fibrous phases, changes in deformation property and abrasion resistance of concrete were positive.

The X-ray phase data show that the use of a complex chemical admixture of a new generation in combination with a reactive aggregate has a high activating effect on hardening concrete, which is better that heat treatment and steam curing. 
By comparing two roentgenograms made for samples 1 and 4 , one can see new hydrate phases on the roentgenogram 4 (complex chemical activation), which are not on the roentgenogram 1 (steam curing). These phases promote bonding of concrete components, forming a strong and uniform structure.
The X-ray phase data were validated by differential-thermal data provided by comprehensive physico-chemical studies of hardened paste samples. Differential-thermal data are presented in Table 4.

Table 4: Comparative Differential-Thermal Data on Modified Concrete Hardened under Normal Conditions and Cured by Steam

\begin{tabular}{|c|c|c|c|c|c|c|c|c|c|c|c|c|c|}
\hline & \multicolumn{6}{|c|}{ Endotherms } & \multicolumn{6}{|c|}{ Resulted Loss, \% } & \multirow[b]{2}{*}{ 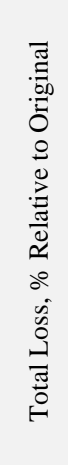 } \\
\hline 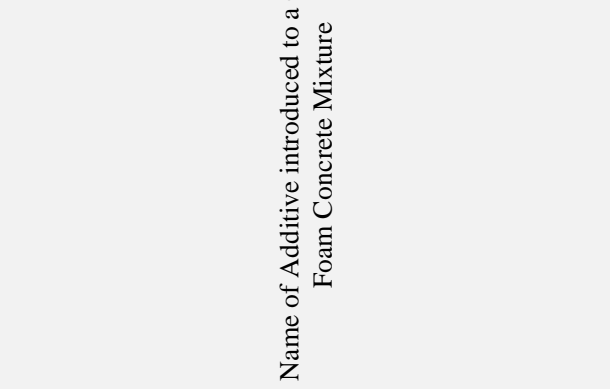 & I & II & III & IV & V & VI & I & II & III & IV & $\mathrm{V}$ & VI & \\
\hline 1 & 2 & 3 & 4 & 5 & 6 & 7 & 8 & 9 & 10 & 11 & 12 & 13 & 14 \\
\hline Concrete, no additives $(\mathrm{N})^{* *}$ & 138 & 193 & - & 538 & - & - & 8.0 & 9.0 & - & 8.8 & - & - & $\begin{array}{c}25,8 / \\
123\end{array}$ \\
\hline Concrete, admixture added & $\begin{array}{l}(-) \\
140\end{array}$ & $\begin{array}{c}(-) \\
206\end{array}$ & - & $\begin{array}{c}(-) \\
531\end{array}$ & $\begin{array}{c}(-) \\
748\end{array}$ & $\begin{array}{c}(+) \\
810- \\
830\end{array}$ & 10.5 & 11.5 & - & 0.5 & 9.5 & - & $\begin{array}{c}32,0 / \\
152\end{array}$ \\
\hline $\begin{array}{l}\text { Concrete, admixture added in combination with reac- } \\
\text { tive aggregate }\end{array}$ & $\begin{array}{l}(-) \\
143\end{array}$ & $\begin{array}{c}(-) \\
210\end{array}$ & $\begin{array}{c}(-) \\
380\end{array}$ & - & $\begin{array}{c}(-) \\
740- \\
790\end{array}$ & $\begin{array}{c}(+) \\
800- \\
830\end{array}$ & 11.6 & 14.2 & - & - & 9.5 & - & $\begin{array}{c}35,3 / \\
168\end{array}$ \\
\hline
\end{tabular}

Note: SC-Steam curing; $N$-Normal conditions of hardening Table 4 confirms the findings, which are as follows: concrete without chemical activation, hardened under normal conditions or cured by steam, is characterized by the formation of complex hydrate compounds and similar hydration intensity at 28 days;

- $\quad$ chemical admixture of a new generation enhances the hydration process and promotes the formation of new hydrate phases, defined as low-basic CSH (I) group hydrosilicates with a molar ratio, $\mathrm{Ca} / \mathrm{Si} \approx 0.8$ (at $830^{\circ} \mathrm{C}$ above zero), nekoite $3 \mathrm{CaO} \cdot 6 \mathrm{SiO}_{2} \cdot 8 \mathrm{H}_{2} \mathrm{O}$ (at $748^{\circ} \mathrm{C}$ below zero; at $830^{\circ} \mathrm{C}$ above zero) and afwillite (at range $810-830^{\circ} \mathrm{C}$ above zero);

- $\quad$ complex chemical activation is illustrative of high compatibility between the developed chemical admixture and a reactive aggregate, which in combination enhance the hydration process and the formation of hydrate compounds from magnesium carbonate (at $390^{\circ} \mathrm{C}$ below zero; at range 740 $790^{\circ} \mathrm{C}$ below zero).

\section{Conclusion}

1. By comparing with heat treatment, preparing of high strength concrete with unique properties by complex chemical activation was established to be more effective when using chemical admixture of a new generation in combination with a reactive aggregate.
2. A chemical admixture containing $\mathrm{SiO} 2$ nanodispersions enhances the hydration process and improves the flexural strength, crack resistance and hardness of concrete.

3. The use of a chemical admixture in combination with a reactive aggregate improves the deformation properties of high strength concrete, improves durability, frost resistance, and resistance to other aggressive external impacts. It also makes the product more resistant to abrasion.

4. Modified high-strength concrete with unique properties can be recommended for use in the construction of essential facilities.

\section{References}

[1] Svatovskaya, L. B., Sychova, A. M., Soloviova, V. Y., Maslennikova, L. L., \& Sychov, M. M. (2016). Obtaining Foam Concrete Applying Stabilized Foam. Indian Journal of Science and Technology, 9(42).

[2] Svatovskaya, L. B., Sychova, A. M., Soloviova, V. Y., Maslennikova, L. L., \& Sychov, M. M. (2016). Absorptive Properties of Hydrate Silicate Building Materials and Products for Quality and Geoecoprotection Improvement. Indian Journal of Science and Technology, 9(42).

[3] Kondratov, V., Solovyova, V., \& Stepanova, I. (2017). The development of a high performance material for a ballast layer of a railway track. Procedia engineering, 189, 823-828.

[4] Boikova, T., Solovyov, D., \& Solovyova, V. (2017). Concrete for Road Pavements. Procedia engineering, 189, 800-804. 
[5] Boykova, T. I., Solovyova, V. Y., \& Solovyov, D. V. (2017). Effective Repair and Refurbishment Compound for the Strengthening of a Road Concrete Pavements. Procedia engineering, 189, 650-653.

[6] Svatovskaya, L., Sychova, A., Sychov, M., \& Okrepilov, V. (2016). New Parameter of Geoecological Protective Ability of Construction Articles. In MATEC Web of Conferences (Vol. 53, p. 01024). EDP Sciences.

[7] Svatovskaya, L., Sychova, A., Sychov, M., Okrepilov, V. (2016). Quality Improvement of Concrete Articles. MATEC Web of Conferences 53, 10-23

[8] Sakharova, A., Svatovskaya, L., Baidarashvili, M., \& Petriaev, A. (2016). Sustainable Development in Transport Construction through the Use of the Geoecoprotective Technologies. Procedia engineering, 143, 1401-1408.

[9] Svatovskaya, L., Kabanov, A., \& Sychov, M. (2017). The Improvement of Foam Concrete Geoecoprotective Properties in Transport Construction. In IOP Conference Series: Earth and Environmental Science, 90(1), 10.

[10] Svatovskaya, L., Kabanov, A., \& Sychov, M. (2017). Lithosynthesis of the properties in the transport construction on the cement base. In IOP Conference Series: Earth and Environmental Science. 90(1)

[11] Svatovskaya, L., Kabanov, A., \& Sychov, M. (2017). Soling, Aerating and Phosphating for Soil Strengthening and Detoxication. Procedia engineering, 189, 398-403.

[12] Svatovskaya, L., Urov, O., \& Kabanov, A. (2017). Geoecoprotective technology of transport construction using silica sol absorption method. Procedia engineering, 189, 454-458.

[13] Shershneva, L. S. M., Sychova, M. B. A., Yakimova, T. T. N., \& Khitrov, A. V. (2004). Foam concrete construction demolished waste. In Sustainable Waste Management and Recycling: Construction Demolition Waste: Proceedings of the International Conference Organised by the Concrete and Masonry Research Group and Held at Kingston University-London on 1415 September 2004, 199.

[14] Svatovskaya, L. B., Sakharova, A. S., Baidarashvili, M. M., \& Petriaev, A. V. (2014). Building wastes and cement clinker using in the geoecoprotective technologies in transport construction, Computer Methods and Recent Advances in Geomechanics. In Proceedings of the 14th Int. Conference of International Association for Computer Methods and Recent Advances in Geomechanics, IACMAG, 152.

[15] Sychova, A. M., Svatovskaya, L. B., Mjakin, S. V., Vasiljeva, I. V. (2009). Modification of fillers for cements (Book Chapter). Electron Beam Modification of Solids: Mechanisms, Common Features and Promising Applications, 35-37.

[16] Sychova, A. M., Svatovskaya, L. B., Mjakin, S. V., Vasiljeva, I. V. (2009). Activation of aqueous phase at cement and concrete solidification (Book Chapter). Electron Beam Modification of Solids: Mechanisms, Common Features and Promising Applications. 39-47.

[17] Maslennikova, L. L., Svatovskaya, L. B., Mjakin, S. V., Vasiljeva, I. V. (2009) Activation of reactions at solid-solid interfaces. Improvement of ceramics materials (Book Chapter). Electron Beam Modification of Solids: Mechanisms, Common Features and Promising Applications. 57-61.

[18] Sychova, A., Sychov, M., \& Rusanova, E. (2017). A Method of Obtaining Geonoiseprotective Foam Concrete for Use on Railway Transport. Procedia engineering, 189, 681-687.

[19] Sychova, A., Solomahin, A., \& Hitrov, A. (2017). The Increase of the Durability and Geoprotective Properties of the Railway Subgrade. Procedia engineering, 189, 688-694.

[20] Kavetsky, A., Yakubova, G., Sychov, M., Lin, Q., Walter, G., Chan, D., ... \& Bower, K. (2008). Tritium-charged capacitor. Nuclear science and engineering, 159(3), 321-329.

[21] Kavetsky, A. G., Meleshkov, S. P., \& Sychov, M. M. (2002). Conversion of radioactive decay energy to electricity. Polymers, Phosphors, and Voltaics for Radioisotope Microbatteries, 9.

[22] Jamshidi, A., Kurumisawa, K., Nawa, T., Samali, B., \& Igarashi, T. (2017). Evaluation of energy requirement and greenhouse gas emission of concrete heavy-duty pavements incorporating high volume of industrial by-products. Journal of Cleaner Production, 166, 1507-1520.

[23] Nishizawa, T., Furukawa, M., Nagata, K., Hyodo, H., \& Ueda, N. (2017). A structural model of interlocking concrete block pavements for heavy duty roads. Journal of Japan Society of Civil Engineers, Ser. E1 (Pavement Engineering), 73(3). 